To Cite: Mondon, Aurelien and Aaron Winter. 2020. 'Racist Movements, the Far Right and Mainstreaming'. Routledge International Handbook of Contemporary Racisms, ed. John Solomos. Abingdon: Routledge. ISBN 9781138485990

\title{
Chapter 12: Racist movements, the far right and mainstreaming
}

\section{Aurelien Mondon and Aaron Winter}

We have recently witnessed a resurgence and mainstreaming of the far right across much of the west, but also in countries like Brazil. In the UK, we have seen the deep influence of UKIP on mainstream politics, the street activism of the English Defence League (EDL) and Britain First, and wider support for anti-immigrant and anti-Muslim politics and their role in the Brexit victory. In the US, we have witnessed the election of Trump, whose campaign and nativist, antiimmigrant and anti-Muslim policies have been endorsed and supported by the white nationalist alt-right and wider racist extreme right, including David Duke, the Ku Klux Klan and Stormfront. There have also been strong electoral performances in France by the Front National, Alternative für Deutschland (AfD) in Germany, Dansk Folkeparti (DF) in Denmark and Jobbik in Hungary, while Freiheitliche Partei Österreichs (FPÖ) in Austria, Lega in Italy and Fiddesz in Hungary entered government as coalition partners.

Beyond parties, new anti-immigrant and anti-Muslim protest movements such as the Generation Identity, the EDL and PEGIDA have developed in Europe. These movements often have ties with parties, but provide different avenues for recruitment and allow for more radical approaches, which could prove alienating to voters for parties involved a more mainstream strategy. In addition, there has also been a rise in hate crimes in many of these contexts. This all occurs in liberal democracies that have, since the Second World War, seen themselves as having defeated and expunged fascism, and self-righteously 'post-racial'. That is not to say that far right activity had disappeared, but that in many cases the far right came to be seen as both an unacceptable remnant of the illiberal pre-war period and embodiment of racism in the post-race context.

As Eduardo Bonilla-Silva and Victor Ray (2015) pointed out, this is not surprising as racism is commonly thought of today as 'individual-level animosity or hatred towards people of colour', and associated primarily with its most explicit and historical manifestations or representations, such as 'Klan rallies or overt racial behaviour like hanging a noose from a tree' (Bonilla-Silva with Ray 2015: 59). This perspective or take on racism not only conveniently misses ongoing structural and institutional racism and racial inequality that were not defeated with the Nazis or the Klan (before the latter's many revivals), but the discursive reconstruction of the far right in ways that displaced or concealed their racism under a liberal veneer. Following from this, it is important to note that despite the far right being widely seen as the form in which racism takes place in the post-war and post-race context, research and scholarship on what we refer to as 'racist movements', tends to occur in political science and looks at them as part of the 'extreme', 'far', 'radical' or 'populist' right, as opposed to racism proper. Racism and xenophobia are often viewed as characteristics in a terminological frame- work or taxonomy, as opposed to constitutive. The focus of such work tends to be where they sit on the political spectrum. Furthermore, in such studies, they are often constructed as a threat to post-war liberal democracy rather than racialised people who they target, as if liberal democracy was a safeguard in itself rather than a potential enabler of racist practices. While this is a specific analytic formulation and approach, as opposed to the traditional survey or overview, we believe it is necessary to understand the contemporary landscape of racist movements, how they emerged in particular forms, including the denial of racism and white victim narratives, and their mainstreaming. 
In this chapter, we examine contemporary racist movements. In the first section, we look at

what and who 'racist movements' are. In the second section, we look at a range of approaches to defining and researching racist movements, often under other labels which can sometimes sideline focus and analysis of racism. In Section 3, we look at the concept and position of racist movements in the post-racial era, where they stand in for racism itself. Finally, in the fourth which challenges concepts such as 'extremist' and the function of racist movements as the embodiment of racism.

\section{Racist movements}

When considering 'racist movements', one's thoughts often turn to a series of historical and contemporary notables: The Ku Klux Klan, alt-right, Nazis, Oswald Mosley's British Union of Fascists, the National Front, British National Party (BNP), EDL, Britain First, PEGIDA, Front National, Lega and others. Yet, when the phenomenon is studied, it is often labelled instead 'extreme', 'far' or 'radical' right, and more recently and perhaps most incorrectly 'populism', with racism de-emphasised or even removed. According to Kathleen Blee (2013),

Racist movements are organized, collective efforts to create, preserve, or extend racial hierarchies of power and privilege. Such movements explicitly espouse the ideologies of white supremacism and/or anti-Semitism (anti-Judaism or hatred of Muslims or Arabs) that were consolidated in the Western world in the eighteenth and nineteenth centuries.

While this is a good starting point, it is worth noting here that the point of reference is now discarded historical ideas. Moreover, the historical roots of such ideas do not limit their continuing transmission, legacy and structural impact, and the representation of the far right as their contemporary manifestation is a construction that distracts from that legacy, as well as systemic and liberal racism.

Although this is far from exhaustive, the types of organisations we define as racist movements include political parties, social movements (protest and street activists), violent and paramilitary, media and intellectual platforms. It may also be the case that there is overlap or duel functions and repertoires, such as in the cases of the BNP and Britain First which have engaged in street activism and elections, with the latter also engaging in paramilitary train- ing and harassment during street protests. There are also larger networks and subcultures, and linked to these, (new) media platforms, such as The Daily Stormer, The Right Stuff and Gab, that allow movements, affiliated and non-affiliated individuals to participate and engage.

Within these formations are specific ideological types including fascists and neo-Nazis, white supremacists, white separatists, neo-confederates, Identitarians, anti-Muslims, anti- immigrants and combinations of these. These also contain diverse variations, such as a white supremacy or fascism founded upon specific theologies or ideologies, such as Christian Identity. They may also be regionalist, nationalist (including separatist) and/or imperialist in their identity, location or political orientation, and system or state supportive and hegemonic or oppositional and counterhegemonic, although they are typically hegemonic in terms of race even when claiming, for example, that whites are marginalised and victimised.

It is also important to recognise the role of the individual and the ways in which racism within society allows and produces individualisation in cases of white extremism. In recent years, the 'lone wolf' trope has become increasingly popular to describe extreme right attacks, leading to some commentators lamenting on the double standards within analyses of terrorism. Attacks seemingly conducted in the name of Islam are usually treated as terrorist in nature, both by politicians and the media, while extreme right attacks, even those with clear and avowedly terrorist intent, have been portrayed as the acts of mad or bad individuals or aberrations. Yet, research shows that more often than not the individual is linked to a movement or radicalised by one. This was made particularly obvious in the wake of the attack conducted by 
Anders Breivik on 22 July 2011 when he bombed a government building in Oslo, killing eight people, and committed a gun attack on a youth Labour Party gathering on Utøya, killing 69. He was widely described as a 'lone wolf', despite having been part of Norway's powerful far right Progress Party for a number of years. A similar kind of individualisation took place in the case of Thomas Mair who murdered UK Labour MP Jo Cox in Birstall at the height of the EU Referendum campaign. Despite clear links to a number of organisations and their programmes and ideologies, Mair was widely described as a mentally unstable loner by UKIP and Leave.EU leader Nigel Farage ('one man with ser ious mental health issues'); Spiked!'s Brendan O'Neill ('warped killer'); and The Daily Mail ('loner' seeking counselling) (Winter 2017).

The relationship between the extreme right, individualisation and racial privilege come together in the case of Timothy McVeigh who bombed the Murrah Federal Building in Oklahoma City on 19 April 1995, killing 168. In the Time magazine issue on the bombing, the cover image was of McVeigh's mugshot with the headline 'The Face of Terror'. In the related article, Elizabeth Gleick argued that 'a sense of guilty introspection swept the country when the FBI released the sketches of the suspects, distinctly Caucasian John Does one and two'. Mike Hill argued that more than guilt and introspection, the image and headline were terrifying to Time's implied white readers because they rendered whiteness distinct or particular, as opposed to universal, as it became directly implicated in the terror (Hill 1997). Yet, this was wishful thinking. The hegemonic universalism that renders whiteness invisible and non-racialised (to itself) is not challenged by the act of an individual (or even a suspicious pattern of individuals, who happen to be aligned with a movement), because the opposite of white universalism is not particularism, but individualism (Winter 2010). This occurred despite his links to the wider anti-government extreme right that had been active throughout the 1980s and 1990s.

\section{Defining and researching racist movements}

While we have Blee's definition of 'racist movements', as noted, within the literature terms such as extreme, far and radical right have been used over the years, at times interchangeably, to describe a myriad of movements and parties that have racist identities and hold racist ideologies, from more mimetic iterations of fascism and Nazism to nationalist parties with no ties to historical ideologies. There is a lack of consensus, not only on the appropriate terminology, but also on which features should be used to define such a disparate ideological family, and racisms are typically only part of the picture. According to Cas Mudde in 2007:

Without claiming to be exhaustive, titles of (comparative) books and articles in various languages on the topic include terms like extreme right, far right, radical right, right, radical right-wing populism, right-wing populism, national populism, new populism, neopopulism, exclusionary populism, populist nationalism, ethno-nationalism, antiimmigrant, nativism, racism, racist extremism, fascism, neofascism, postfascism, reaction-ary tribalism, integralism, antipartyism. The terminology chaos is not the result of fundamental difference of opinion over the correct definition; rather, it is largely the consequence of a lack of clear definition.

The term used depends on a variety of factors, including context, politics (of the movement and scholar) and discipline. Literature on these comes primarily from Political Science and Politics, and includes country and movement case studies, electoral analysis, organisation analysis, ideological (type) analysis, as well as work on (and long-standing debates about) definitions themselves.

Throughout the 1990s and until the late 2000s, the term extreme right was probably the most commonly used to describe the resurgence of parties such as the Front National or the FPÖ. Mudde (1997) has listed at least fifty-eight possible characteristics which identify and define the extreme right, including racism, anti-Semitism, xenophobia, anti-communism, nationalism, patriotism, libertarianism or authoritarianism, paramilitarism, violence, terrorism and 
conspiracism. Such taxonomic definitions allow for the identification and inclusion of new phenomena, although they are typically based on manifestations in different historical, political and geographical contexts. Where new characteristics are encountered these can be included and the category can be expanded. As such, taxonomic definitions can be either analytically reductionist in their application, historically presentist in their use or apply to characteristics that exist across the political spectrum, including the mainstream at times. It should also be noted that there was also an uptake in uses of and scholarship on 'fascism' (and varieties thereof) applied to contemporary movements at the same time, highlighting the shadow cast by Nazism on the recognition and analysis of later movements and parties (see Griffin 1993, 1995).

The use of the term extreme right changed with the seminal work carried by Mudde on the populist radical right in the mid-2000s, which he defined as having three main characteristics: nativism, authoritarianism and populism. More recently, we have also witnessed the revival (and hype) of the term populism in response to Brexit, Trump and so-called radical right populist parties in Europe (Glynos and Mondon 2016). We have also seen the rise of new terminology, such as the alt-right, coined by leader Richard Spencer, which has not only added to the number of terms used, but led to debates over the use of movement self- definition by the media, researchers and analysts, particularly as this one conceals the movement's extremism, racism, white supremacism/white nationalism and fascism under the more acceptable and edgy 'alt'/alternative moniker. Moreover, it is also a looser network of activists than traditional movements, and operates on diverse online and offline platforms. In a sense though, these characteristics may also be key to understanding media interest and the movement's success mainstreaming racist extreme right ideas (Winter 2019).

These issues are complicated further by attempts to position these parties and movements on the political spatial spectrum, and what status their defining characteristics, such as racism, have in contemporary society. For example, Minkenberg (1997: 84-85) argues that these parties and movements "are "extreme" not in terms of being against or outside the existing constitutional order but in terms of being extreme within it'. They abide by 'a belief system that does not share the values of the political order within which it operates'. Martin Durham (2000: xii) has attempted to establish clear taxonomic definitions and boundaries between the mainstream, extreme, far and radical right. Those committed to white supremacy and anti-Semitism are best defined as extreme right, while non-racist conspiracists are best defined as radical right. Where there is ambiguity, indecision or overlap, Durham makes use of the term far right.

In our definition and approach, we foreground racism and have decided to reserve the use the term extreme right for those movements and activists who express illiberal articulations of racism and may engage in violence. We use the term far right to describe movements and parties that espouse a racist ideology, but do so in an indirect, coded or even covert manner, by focusing notably on culture and/or occupying the space between illiberal and liberal racisms, between the extreme and the mainstream. This can be witnessed in what we call the reconstructed far right. Such movements and parties may challenge mainstream parties and be more explicit in their ideologies and agendas, but these differences are exaggerated by the mainstream to establish its liberal self-image and hegemony.

If anything, all of this tells us that how we understand and define such phenomena is not fixed across different historical and political contexts and disciplines. These differences can reflect changes to the movements in question, their relationship to the main-stream or centre, what is acceptable political discourse, and the function of such terminology (or the scholars' analysis or objectives). It is worth noting here that the term 'radical right' was coined by Seymour Martin Lipset (1955), to describe movements, organisations and actors, including the Ku Klux Klan, John Birch Society and McCarthy- ism, that sought 'far-reaching changes in American institutions', rejecting tolerance, establishment conservatism and democratic procedures, such as lobbying and the ballot box, in favour of agitation and practices which threatened 'to undermine the social fabric of democratic politics'. While Lipset identified the rejection of tolerance as a characteristic, the conceptualisation can be 
seen as a normative defence of the main- stream liberal democratic system and order, which was racist and anti-communist, and its accepted procedures, which were also used to express and maintain these. Crucially, these new movements, and associated typologies, coincided with the emergence of the post-war liberal order, the second phase of the Cold War (both following the defeat of the Nazis) and the American battle over desegregation and civil rights. Paul Hainsworth's framing of his book The Politics of the Extreme Right: From the Margins to the Mainstream, a central concern of the early 2000s literature, is telling here:

historians and political commentators will look back upon a century of extremism, in which fascism and intolerance figured prominently, and to devastating effect. Total war, Holocaust, ethnic cleansing and scapegoating of 'the Other' have marked the past hundred years of Western civilization. The mid-point of the century, of course, witnessed the defeat of Nazi and fascist forces and signalled - in the West - the victory of liberal democratic ideas, rooted in pluralism, multi-partyism, a renewed assertion of dignity of the individual and a respect for human rights (Hainsworth 2000: 1).

While fascism and Nazism cast a shadow over the definitions and analysis, and for Lipset and Raab The Politics of Unreason: Right Wing Extremism in America, 1790-1970 (1970), desegregation and civil rights provide the context, it is notable that racism is not foregrounded or prioritised in work on the extreme, far or radical right. This is partly because of the dominance of political scientists working on the topic. There is also work in other disciplines that addresses race and racism more prominently, particularly in Sociology, Social Psychology, Criminology, History, Anthropology and Politics. The terms used for the movements in question include racist movements, hate groups, and, to a lesser extent, extreme and far right. Notable examples include Michael Billig's Fascists: A Social Psychological View of the National Front (1979), Raphael Ezekiel's The Racist Mind: Portraits of American Neo-Nazis and Klansmen (1996), Jessie Daniels' White Lies: Race, Class, Gender, and Sexuality in White Supremacist Discourse (1997), Jeffrey Kaplan and Tore Bjorgo's edited collection Nation and Race: The Developing Euro-American Racist Subculture (1998), Kathleen Blee's Inside Organized Racism: Women in the Hate Movement (2002) and more recent Understanding Racist Activism: Theory, Methods, and Research (2018), and Sindre Bangstad's Anders Breivik and the Rise of Islamophobia (2014). There are also studies of movements, that focus more on racism, in terms of a range of sub-themes and issues, utilising a range of methods and theoretical approaches. A non-exhaustive list with a small selection of examples includes: activism (Dobratz and Shanks-Meile 2000; Klandermans and Mayer 2006; Simi and Futrell 2015); gender (Blee 2002; Daniels 1997; Ferber 1998; Sanders-McDonagh 2018); online (Back, Keith and Solomos 1998; Daniels 2009; Perry and Scrivens 2016; Winter 2019); history (Berlet and Lyons 2000; Chalmers 1965; Copsey and Richardson 2015; Copsey and Worley 2018; Macklin 2007; Webb 2010; Winter 2018); class (Rhodes 2011; Rydgren 2012); popular culture (King and Leonard 2014; Miller-Idriss 2017); terrorism and violence (Adamczyk, Gruenewald, Chermak and Freilich 2014; Winter 2010, 2018); mainstreaming (Mondon 2013; Winter 2017, 2019), and specific country-based cases (e.g. Mondon 2014 on France); and a wealth of work on the altright in the current context (Hawley 2017; Neiwert 2017; Wendling 2018). There is also work (including amongst these examples) that focus on movements and organisations or individuals, particular contexts or comparative analysis, while some are critical analyses and others more practical problem solving in function (e.g. deradicalisation, security and policing). There is also some work in the field of race and racism studies, that addresses racist movements, but they are positioned as a minor aspect or part of the landscape of contemporary racism that is largely defined and determined by structural and institutional forms (e.g. Anderson 2016; Bonilla-Silva 2001; Omi and Winant 1994; Solomos 2003; Wieviorka 1995) This is something that needs to be highlighted as racist movements can often stand in for and/or distract from racisms more broadly. 


\section{Racist movements and the post-racial}

Just like the fact that when racist movements are studied, their racism can be de-emphasised, in some cases when they are the focus of study or when racism is discussed in the media and wider society, ironically, such racist movements come to stand in for and embody racism itself. We can see this in past and current panics about the far right bringing racism back into the mainstream, or the denial of systemic and everyday racism that is based on a comparison to 'real' racism from the past or in extreme forms, which we call illiberal. Often, these are based on the notion that racism has been defeated, because the Nazis or the Klan have, and paradoxically, that mimetic acts are the only remaining forms, thus foreclosing on recognition of systemic and contemporary mainstream forms and manifestations.

Examples of this could be seen particularly in responses to Obama's election. In one editorial image, 'Obama and resigned KKK member', by Riber Hansson (2008), Obama is shown walking up the White House passing a Klansman looking downcast and leaning on his cross. Of the election, Richard Cohen (2008), of the Washington Post, wrote 'it is not just that he is postracial; so is the nation he is generationally primed to lead', and quoting Lyndon John- son, 'we have overcome'. The image used is of police attacking voting rights marchers at the Edmund Pettus Bridge, which was still named after the former Senator and Grand Dragon of the Alabama Klan, in Selma on 'Bloody Sunday', 7 March 1965.

In the UK, following the post-Brexit rise in hate crimes, Brendan O'Neill (2016), the editor of far right libertarian Spiked! argued in The Spectator:

there is a great disparity between the handwringing over hate crime and what Britain is actually like. The open racism even I can remember in the 1980s has all but vanished ... The likes of the BNP and EDL have withered due to lack of interest.

UKIP founder and former leader Nigel Farage (2016) claimed that:

I destroyed the British National Party - we had a far right party in this country who genuinely were anti-Jew, anti-Black, all of those things, and I came along, and said to their voters, if you're holding your nose and voting for this party as a protest, don't. Come and vote for me - I'm not against anybody, I just want us to start put- ting British people first, and I, almost single-handedly, destroyed the far right in Brit-ish politics.

This occurred despite, or perhaps because of, the fact that UKIP is widely seen as the inheritor of the BNP's politics and a mainstreaming version, something we will return to in the section on discursive reconstruction. In France, Jean-Marie Le Pen was for a long time used as a scarecrow, and regularly described as the 'filthy beast' (la bête immonde), a direct reference to Nazism and fascism. This in turn facilitated the ignorance of racism within mainstream politics in France, particularly expressed towards Muslim communities, but also allowed Marine Le Pen to pitch herself as moderate compared to her father, while being literally the heir of the old order.

It is often an effect or product of historical narratives that celebrate victory over historical enemies. This can be seen in post-war celebrations of the defeat of Nazism across the liberal democratic west, as well as more specifically in the more recent case of Winston Churchill, whose racism is defended with recourse to both being a man of his time and having defeated the Nazis (no comment on Empire and colonial racism which continued) (Burrows 2018; Sky News 2019). This narrative would be replayed for all of Britain following the defeat of post-war fascists such as the National Front in the 1980s and the BNP in early 2000s, as the O'Neill quotation illustrated. Whereas in the US, the ability to conflate racism and the extreme (as well as far) right separates them both from the mainstream, and sees them as defeated, a discursive construction that furnishes the post-racial narrative and mythology that accompanied Obama's election was the product of a series of developments in the 1960s. These were the FBI COINTELPRO White Hate Groups Programme from 1964 and HUAC hearings into the 
Activities of the Ku Klux Klan Organization from 1965, which condemned the group as terrorists

and un-American, which greatly diminished the organisation just as Civil Rights and Voting Rights had passed (Winter 2018), paving the way for post-race.

The notion that racism is defined by the extreme or far right is part of the construction of what we term 'illiberal racism'. This is racism defined by extreme and historical movements, such as Nazism, the Klan or National Front, as well as corresponding beliefs and ideologies such as biological racism, white supremacy and blood and soil nationalism, and practices such as slavery, colonialism, and segregation, which were once part of the mainstream, but have been cast out as illiberal and unacceptable in the liberal post-war and post-civil rights eras. This is evident when Hainsworth refers to Nazism in his analysis of the mainstreaming of the extreme right and Blee defines racist movements in terms of racist ideologies of the eighteenth and nineteenth centuries. Yet, this ignores systemic racism and inequality in favour of the illusion (and defence) of colourblindness and perpetuation of colourblind or liberal racism.

This echoes Bonilla-Silva's 'racism without racists' (2006), and particularly, his two frames of abstract liberalism and cultural racism. The former is 'an abstract manner to explain racial matters' and even celebrate racial progress (as a liberal achievement): with each person being now equal in rights and opportunity, proof of which is based on individual achievement universalised, white people can righteously claim that barriers have been lifted and the onus in on the (liberal) individual to make their own life, ignoring thus the structural and systemic racial inequalities still in place.

According to Tim Wise, commenting on this liberal post-racial frame being used in reference to Obama, the election did not signify the death of racism, but the usurpation of 'Racism 1.0,' the 'old-fashioned bigotry ... that has long marked the nation's history: the kind that, in its most extreme moments has precipitated racist murder, lynching, and terror' (illiberal racism in our terms) by 'Racism 2.0.' (Wise 2009: 26). That is, 'enlightened exceptionalism a form that allows for and even celebrates the achievements of individual persons of color' (abstract liberalism in Bonilla-Silva's terms and liberal racism in ours). Yet, as Wise points out supports, 'Racism 1.0' persists and 'animates hate groups and hate crimes' (Wise 2009: 26), something we saw in the racist extreme and far right backlash to Obama's election and resurgence under Trump.

The second frame, cultural racism, shifts the focus from race to culture (and religion in the case of Muslims) and blame that for the inferior standing of minorities (see also Balibar and Wallerstein 1997; Barker 1982). We see this in movements and discourses that deny their racism and articulate it through liberal causes, such as women's rights, LGBTQ+ rights, free speech and democracy (Mondon and Winter 2017a), which has been central to what we term 'discursive reconstruction' and one of the keys to mainstreaming.

\section{Discursive reconstruction, the liberal turn and mainstreaming}

If the war marked a shift in how racism was perceived, so too did the social upheaval of the 1960s and 1970s. The extreme right would play the functional role of illiberal scarecrow for the liberal mainstream to distract from the liberal racism. While some embraced this extremism, others attempted to reshape their discourse and strategy to adapt to their new context in a more counter-hegemonic fashion. In the post-war period, the Klan very much played the functional boogieman in the US. Yet, what is often ignored is just how embedded in the mainstream they were. While the American far and extreme right moved from the mainstream to the more extreme in the post-civil rights era, abandoning the state for political insurgency, white supremacy for white separatism, Protestantism for Christian Identity and Odinism and the Klan for more overtly fascist movements such as Aryan Nations and National Alliance, in Europe the picture would be different (at least until the Trump era and emergence of the alt-right). 
The response to the post-war and post-1960s consensus involved a process of discursive reconstruction to ensure electoral credibility. While the process has been uneven and has very much depended on context, some trends have become common in the reshaping of extreme right politics into more moderate far right politics. The impetus towards discursive reconstruction really took shape in the 1980s, when groups of intellectuals devised ways for the extreme right to escape the position it had been forced in after the defeat of fascism in the Second World War. The illiberal nature of extreme right discourse, based on biological racism and fascist nostalgia, was further marginalised by the rise of progressive counter-movements in the 1960 s based on second-wave feminist, civil rights, anti-colonial and anti-racist ideas. As extreme right support reached a nadir and as conservative mainstream parties on the right were forced to give way to a number of progressive measures, it became necessary for the more strategically-minded actors on the right-wing fringe of politics to seek a way out of the margins without diluting their ideological roots. For this to be possible, the extreme right needed to engage in a process of discursive reconstruction which would provide it with a way into the mainstream by separating it from the more illiberal forms of right-wing politics. This manifested in their discursive rejection of the extreme right, although links between both would remain alive, albeit concealed. Biological racism was increasingly replaced by the cultural racism referred to by Bonilla-Silva, mostly targeted against Muslim communities, and populism became central to their discourse.

In France, this would see the Front National (see amongst others, Crépon, Dézé and Mayer 2015; Mondon 2013, 2014) initiated by neo-fascist Ordre Nouveau in 1972 and led by fascist, anti-Semite Jean-Marie Le Pen, their first president, move away from crude racism, and instead focus on 'culture' and Islam as a convenient scapegoat. This would be something which proved particularly effective in France where the concept of laïcité (secular-ism) had already turned into a reactionary tool to push racist agendas (Mondon 2015). In the 21st century, and even more so under the new leadership of Marine Le Pen, who embraced liberal tropes of free speech and women's rights, as well as philosemitism, against Muslims and the illiberal fascism of her father's party.

In the UK, the story was again different. Pre-war, the extreme right was represented by Oswald Mosley's British Union of Fascists and post-war by the National Front. Yet, the place occupied by the nation as the last standing bulwark against Nazism and fascism in the Second World War has given a particular twist to the way the extreme and far right have organised This was made particularly clear when Nick Griffin tried to use Spitfires in one of his BNP campaign posters, and faced near universal condemnation as he was automatically linked to the enemy of this national emblem of the fight against the Nazis. The BNP, formed in 1982, proved similarly unsuccessful at shedding its extreme right image decisively despite a few breakthroughs in the 2000s. It was UKIP's lack of ties to the traditional extreme right and Euroscepticism as opposed to open racism that has allowed sup- porters of a more reconstructed approach.

Of particular interest is the way UKIP followed an almost inverted trajectory to that of the FN. Farage's UKIP moved beyond traditional Euroscepticism, found in large swathes of the Conservative party, adding a more targeted fear of the other in the form of Brussels, immigrants and Islam. At the same time, the UK experienced the EDL, whose founder Stephen YaxleyLennon (a.k.a. Tommy Robinson) styled the organisation as both a voice of the working class and champion of free speech, women's and LGBTQ+ rights against Islam and Muslims. As the climate became increasingly polarised and far right (and to a lesser extent more extreme right) issues mainstreamed, what Robinson would say in the late 2010s was no longer as shocking to elite discourse, as when he said it a decade prior from the confines of the extreme right. In fact, like Farage, Robinson was feted by the media and given a frequent platform by the BBC and other outlets (Mondon and Winter 2017b). 
become a popular refrain since the early 2000s (see for example Akkerman, de Lange and

Rooduijn 2016; Hainsworth 2000). Recent events such as Brexit, Trump's election, and the strong performance of a number of far-right parties across Europe have made it an ever more debated issue. This was compounded by a rise in everyday racism and hate crimes, extreme and far right marches and rallies, and mainstream establishment parties legitimising the anti- immigrant and anti-Islam discourse. (see Mondon and Winter 2019). We argue that main- streaming is indeed very much a two-way process and that it cannot take place with the far right as sole agent (e.g. merely moderating): no matter how hard a far right party tries to reform itself, if the broader political system is not open to welcoming it and/or its ideas, it is bound to remain at the margins. The breakthrough of far-right politics has thus necessitated the help of mainstream actors such as politicians of course, but also the media and academics to legitimise, if not their cause, their presence in the political debate. A sense of crisis and urgency is essential for farright ideas to make their way into the mainstream as they require a derogation from the current (and contingent) norms. This is almost always related to the perceived pressure created by the other, whether they are internal (and even citizens at times such as Muslims, Jews or second/third-generation immigrants) or external (refugees, asylum seekers, immigrants). While we are now seeing fascists marching, it is worth noting that the soft liberal racism, which had once denounced the illiberal racism or the far right, also allowed them back in the mainstream through media platforming (e.g. Richard Spencer and Tommy Robinson), free speech, moderation, populist hype and more.

In the UK, we have seen the normalisation of anti-immigrant and anti-Muslim ideas and discourses within the mainstream in ways that legitimise and even mainstream the ideas of the far right, as well as embolden them. Sometimes this is done by mainstream political parties to fend off the alleged threat by the far right (such as the BNP after their electoral success in the early 2000s), but other times this is merely used as justification. This includes the Tory Party's 'Go Home' vans, the 'hostile environment' and Prevent, which have all been used as dogwhistle politics to appease far right voters, emboldening the extreme and far right and ignoring the impact this has had on immigrants, refugees and Muslims and the mainstreaming of certain discourses. In France, this is epitomised by the positioning of Islam and Muslim communities as the other to the concept of laïcité, increasingly understood in reactionary terms. The ban of the hijab in schools in 2004, the burqa in 2010 and more recently the burkini affair in 2016 have all entrenched ideas which were once found on the margins, within the extreme right. In the US, it took Trump's rhetoric about Muslims and Mexicans in the campaign (and eventually office) to bring the extreme and far right in from the cold of the post-civil rights era, but he did not do this alone. It took the influence of Breitbart editor and later Trump advisor Steve Bannon, the emergent alt-right and alt-lite with their white identitarianism and social media savvy, and endorsements from Spencer, Duke and the wider racist extreme right. The mainstreaming process does not only take place through far right and politicians' actions, but the mainstream media and academics have also played a key role in normalising and legitimising liberal Islamophobia and the notion that the 'people' or 'white working class' are in revolt against immigration and Islam in the UK, US and France, and more widely, in ways that make these politics appear democratic as opposed to extreme right (see Mondon and Winter 2018, 2019). What is worth noting is that the mainstreaming process that was founded upon the liberal turn emboldened fascists and white supremacists (and in some cases allowed them back in the fold), but also racist and authoritarian policies from liberal states that used to define themselves in opposition to racist, extremist movements.

\section{Conclusion}

This chapter provides an overview of the literature, definitions and debates about racist movements, particularly focused on the ways in which racism is constructed, ignored or displaced within these. We also offer an analysis of the ways in which racist movements (particularly historical manifestations) have stood in for racism in the post-war and later post- 
racial contexts. We argue that this has made it more difficult to see racism in its deeper, more entrenched systemic forms, but also to understand how such movements have adapted, transformed and mainstreamed, and undergone a resurgence in both liberal and more traditional fascist forms. As a number of parties and movements have reached the gates of power, whether themselves as in the case of the FPÖ in Austria and the Lega in Italy by means of coalition, or through infiltration and radicalisation as was the case for Trump and Orban in Hungary, understanding the role of racism and its impact in our societies is urgent. To do this, it is essential that we move beyond the impact and actions of these parties and movements, but also engage with the role of mainstream actors in the hype and normalisation of certain discourses. Without such a holistic approach, we believe that any victory against the rise of the far right and continuation of racism as a structural and systemic issue will be shortlived.

\section{References}

Adamczyk, Amy, Gruenewald, Jeff, Chermak, Steven, and Freilich, Joshua 2014. 'The Relationship between Hate Groups and Far-Right Ideological Violence'. Journal of Contemporary Criminal Justice, 30(3): 310-332.

Akkerman, Tjitske, de Lange, Sarah L., and Rooduijn, Matthijs eds. 2016. Radical Right-Wing Populist Parties in Western Europe: Into the Mainstream? London: Routledge.

Anderson, Carole. 2016. White Rage: The Unspoken Truth about Our Racial Divide. New York: Bloomsbury.

Back, Les, Keith, Michael, and Solomos, John 1998. 'Racism on the Internet: Mapping Neo-Fascist Sub- cultures in Cyberspace'. Nation and Race: The Developing Euro-American Racist Subculture, eds. Jeffrey Kaplan and Tore Bjorgo. Boston: Northeastern University Press, pp. 73-101.

Balibar, Etienne and Wallerstein, Immanuel. 1997. Race, Nation, Classe; les identités ambiguës. Paris: la Découverte.

Bangstad, Sindre. 2014. Anders Breivek and the Rise of Islamophobia. London: Zed Books.

Barker, Martin. 1982. The New Racism: Conservatives and the Ideology of the Tribe. Frederick: Aletheia Books.

Berlet, Chip and Lyons, Matthew N. 2000. Right-Wing Populism in America: Too Close for Comfort. New York: The Guilford Press.

Billig, Michael. 1979. Fascists: A Social Psychological View of the National Front. London: Academic Press. Blee, Kathleen. 2002. Inside Organized Racism: Women in the Hate Movement. Berkeley: University of California Press.

Blee, Kathleen. 2013. 'Racist Social Movements'. The Wiley-Blackwell Encyclopedia of Social and Political Movements, eds. David A. Snow, Donatella della Porta, Bert Klandermans and Doug McAdam. doi: 10.1002/9780470674871.wbespm443.

Blee, Kathleen. 2018. Understanding Racist Activism: Theory, Methods, and Research. New York: Routledge. Bonilla-Silva, Eduardo. 2001. White Supremacy \& Racism in the Post-Civil Rights Era. Boulder: Rienner.

Bonilla-Silva, Eduardo. 2006. Racism without Racists: Color-Blind Racism and the Persistence of Racial Inequal- ity in the United States. New York: Rowman \& Littlefield.

Bonilla-Silva, Eduardo with Ray, Victor E. 2015. 'Getting over the Obama Hope Hangover: The New Racism in "Post-racial" America'. Theories of Race and Ethnicity: Contemporary Debates and Perspectives, eds. Karim Murji and John Solomos. Cambridge: Cambridge University Press, pp. 57-73. 
Burrows, Thomas. 2018, 9 Oct. 'Why Live in a Country You Loathe?'. The Sun.

www.thesun.co.uk/ news/7452049/piers-morgan-in-extraordinary-gmb-row-with-professorwho-branded-winston- churchill-a-racist-after-astronaut-was-forced-to-delete-tweet-praisingwartime-leader/

Chalmers, David. 1965. Hooded Americanism: The First Century of the Ku Klux Klan 1865-1965. Garden City: Doubleday.

Cohen, Richard. 2008. 'The Election That LBJ Won'. Washington Post. 4 November.

Copsey, Nigel and Richardson, Nigel eds. 2015. Cultures of Post-War British Fascism. Abingdon: Routledge.

Copsey, Nigel and Worley, Matthew eds. 2018. Tomorrow Belongs to Us: The British Far Right Since 1967. Abingdon: Routledge.

Crépon, Sylvain, Dézé, Alexandre, and Mayer, Nonna eds. 2015. 'Les faux-semblants du Front National'. Les Presses de Sciences Po.

Daniels, Jessie. 1997. White Lies: Race, Class, Gender, and Sexuality in White Supremacist Discourse. New York: Routledge.

Daniels, Jessie. 2009. Cyber Racism: White Supremacy Online and the New Attack on Civil Rights. Lanham: Rowman \& Littlefield.

Dobratz, Betty A. and Shanks-Meile, Stephanie L. 2000. 'The White Separatist Movement in the United States: "White Power, White Pride!"'. Baltimore: Johns Hopkins University Press.

Durham, Martin. 2000. The Christian Right, the Far Right and the Boundaries of American Conservatism. Man- chester: Manchester University Press.

Ezekiel, Raphael S. 1996. The Racist Mind: Portraits of American Neo-Nazis and Klansmen. London: Penguin. Farage, Nigel via Press Association. 2016. 'Nigel Farage: I Destroyed Far-Right in British Politics'. The Daily Echo.

Ferber, Abby L. 1998. White Man Falling: Race, Gender, and White Supremacy. London: Rowman \& Littlefield.

Glynos, Jason and Mondon, Aurelien. 2016. 'The Political Logic of Populist Hype: The Case of Right- Wing Populism's 'Meteoric Rise' and Its Relation to the Status Quo'. Populismus Working Paper Series No. 4.

Griffin, Roger. 1993. The Nature of Fascism. London: Routledge. Griffin, Roger. 1995. Fascism. Oxford: Oxford University Press.

Hainsworth, Paul. 2000. The Politics of the Extreme Right: From the Margins to the Mainstream. London: Pinter.

Hansson, Ribor. 2008. 'Obama and Resigned KKK Member'. Cagle Cartoons.

Hawley, George. 2017. Making Sense of the Alt-Right. New York: Columbia University Press.

Hill, Mike. 1997. 'Can Whiteness Speak? Institutional Anomies, Ontological Disasters, and Three Hollywood Films'. White Trash: Race and Class in America, eds. Annalee Newitz and Matt Wray. New York: Routledge, p. 172.

Kaplan, Jeffrey and Bjorgo, Tore eds. 1998. Nation and Race: The Developing Euro-American Racist Subcul- ture. Boston: Northeastern University Press.

King, C. Richard and Leonard, David J. 2014. Beyond Hate: White Power and Popular Culture. Farnham: Ashgate. 
Klandermans, Bert and Mayer, Nonna. 2006. Extreme Right Activists in Europe. Abingdon:

Routledge. Lipset, Seymour Martin. 1955. 'The Sources of the "Radical Right"'. The New American Right, ed. Daniel Bell. New York: Criterion Books, pp. 166-234.

Lipset, Seymour Martin and Raab, Earl. 1970. The Politics of Unreason: Right Wing Extremism in America, 1790-1970. New York: Harper \& Row.

Macklin, Graham. 2007. 'Very Deeply Dyed in Black': Oswald Mosley and the Resurrection of British Fascism after 1945. London: IB Tauris.

Miller-Idriss, Cynthia. 2017. The Extreme Gone Mainstream: Commercialization and Far Right Youth Culture in Germany. Princeton: Princeton University Press.

Minkenberg, Michael. 1997. 'The New Right in France and Germany: Nouvelle Droite, Neue Rechte, and the New Right Radical Parties'. The Revival of Right-Wing Extremism in the 90s, eds. Peter Merkl and Leonard Weinberg. London: Frank Cass, pp. 65-90.

Mondon, Aurelien. 2013. The Mainstreaming of the Extreme Right in France and Australia: A Populist Hegemony? Farnham: Ashgate.

Mondon, Aurelien. 2014. 'The Front National in the Twenty-First Century: From Pariah to Republican Democratic Contender?'. Modern and Contemporary France, 22(3): 301-320.

Mondon, Aurelien. 2015. 'The French Secular Hypocrisy: The Extreme Right, the Republic and the Battle for Hegemony'. Patterns of Prejudice, 49(3): 392-413.

Mondon, Aurelien and Winter, Aaron. 2017a. 'Articulations of Islamophobia: From the Extreme to the Mainstream?'. Ethnic and Racial Studies, 13(40): 2151-2179.

Mondon, Aurelien and Winter, Aaron. 2017b. 'Normalized Hate'. Jacobin. https://jacobinmag.com/ 2017/08/islamophobia-racism-uk-far-right

Mondon, Aurelien and Winter, Aaron. 2018. 'Whiteness, Populism and the Racialisation of the Working Class in the United Kingdom and the United States'. Identities, Online first.

Mondon, Aurelien and Winter, Aaron. 2020. Reactionary Democracy: How Racism and the Populist Far Right Became Mainstream. London: Verso.

Mudde, Cas. 1997. The Extreme Right Party Family: An Ideological Approach. Leiden University. Leiden, Netherlands: Leiden University is the Publisher.

Mudde, Cas. 2007. Populist Radical Right Parties in Europe. Cambridge: Cambridge University Press. Neiwert, David. 2017. Alt-America: The Rise of the Radical Right in the Age of Trump. London: Verso. O'Neill, Brendan. 2016. 'Britain's Real Hate Crime Scandal'. The Spectator. 6 August.

Omi, Michael and Winant, Howard. 1994. Racial Formation in the United States: From the 1960s to the 1990s. New York: Routledge.

Perry, Barbara and Scrivens, Ryan. 2016. 'White Pride Worldwide: Constructing Global Identities Online'. The Globalisation of Hate: Internationalising Hate Crime? eds. Jennifer Schweppe and Mark Austin Walters. London: Oxford University Press, pp. 65-78.

Rhodes, James. 2011. 'It's Not Just Them, It's Whites as Well': Whiteness, Class and BNP Support'. Sociology, 45(1): 102-117.

Rydgren, Jens. 2012. Class Politics and the Radical Right. Abingdon: Routledge.

Sanders-McDonagh, Erin. 2018. 'Women's Support for UKIP: Exploring Gender, Nativism, and the Populist Radical Right (PRR)'. Gendering Nationalism: Articulating Nation, Gender and Sexuality, eds. Jon Mulholland, Erin Sanders-McDonagh and Nicola Montanga. London:

Palgrave MacMillam, pp. 203-219. 
Simi, Pete and Futrell, Robert. 2015. American Swastika: Inside the White Power Movement's Hidden Spaces of Hate. Lanham: Rowman \& Littlefield.

Sky News. 2019, 14 Feb. 'Was Winston Churchill a "Racist" or "Man of His Time"?'. https://news.sky. com/video/was-winston-churchill-a-racist-or-man-of-his-time-11637578

Solomos, John. 2003. Race and Racism in Britain. London: Palgrave-Macmillan.

Webb, Clive. 2010. Rabble Rousers: The American Far Right in the Civil Rights Era. Athens: University of Georgia Press.

Wendling, Mike. 2018. Alt-Right: From 4chan to the White House. London: Pluto Press. Wieviorka, Michel. 1995. The Arena of Racism. London: Sage.

Winter, Aaron. 2010. 'American Terror: From Oklahoma City to 9/11 and after'. Discourses and Practices of Terrorism: Interrogating Terror, eds. Bob Brecher, Mark Devenney and Aaron Winter. Abingdon: Routledge, pp. 156-176.

Winter, Aaron. 2017, 2 Apr. 'Brexit and Trump: On Racism, the Far Right and Violence'. Institute for Policy Research (IPR) Blog. http://blogs.bath.ac.uk/iprblog/2017/04/03/brexit-and-trump-onracism-the-far-right-and-violence/

Winter, Aaron. 2018. 'The Klan is History: A Historical Perspective on the Revival of the Far-Right in "post-Racial" America'. Historical Perspectives on Organised Crime and Terrorism, eds. John Morrison, Andrew Silke, James Windle and Aaron Winter. Abingdon: Routledge, pp. 109-132.

Winter, Aaron. 2019. 'Online Hate: From the Far-Right to the "Alt-Right", and from the Margins to the Mainstream'. Online Othering: Exploring Violence and Discrimination on the Web, eds. Emily Harmer and Karen Lumsden.. London: Palgrave MacMillan, pp. 39-63.

Wise, Tim. 2009. Between Barack and a Hard Place: Racism and White Denial in the Age of Obama. San Francisco: City Lights Books. 